\title{
The Coronation Oath
}

\author{
GRAEME WATT \\ Barrister
}

\begin{abstract}
The oath taken by British sovereigns at their coronations is laid down by a statute dating from 1688. Any oath taken other than in accordance with the correct statutory form is contrary to law. Taking the authorised form of the oath is a condition on which the crown is held by any individual. The oath taken by the present sovereign omitted the promise to govern according to the statutes agreed upon in Parliament. Any variance from the statutory form is problematic but the clause omitted is the clause that most clearly expresses the central concern of the Williamite settlement. The deficiencies in the oath taken, while reasonably apparent, do not appear to have been judicially recognised hitherto. The legal basis of the present oath has been raised in the political sphere but potential difficulties have been set aside on grounds of expediency. Given the unlawfulness of the oath taken, there is a political and constitutional imperative in establishing that deficiencies in the oath do not fatally taint the reign which follows. This article will advance two possible legal means of reconciling an improper oath with a perfectly valid reign.
\end{abstract}

Keywords: Constitution, coronation, oaths, Parliament, monarch

The Coronation Oath Act 1688 (the 1688 Act) requires the sovereign to take an oath in the form prescribed in the Act. The 1688 Act has never been expressly amended but various constitutional statutes have effected amendments by implication. The oaths taken by our present Queen and her late father omit elements which have not been removed from the form of the oath by any legislation. The legality of the oaths thus taken is therefore questionable. The purpose of the present article is to examine: the original statutory authority for the oaths; how this has developed; the necessity of taking the oath in the prescribed form; and whether there are any provisions of law which might ameliorate the failure to adhere to that form.

\section{THE STATUTORY AUTHORITY FOR THE OATHS}

By section 3 of the 1688 Act the sovereign must answer three sets of questions:

Will You solemnely Promise and Sweare to Governe the People of this Kingdome of England and the Dominions thereto belonging according to the Statutes in Parlyament Agreed on and the Laws and Customs of the same?

Will You to Your power cause Law and Justice in Mercy to be Executed in all Your Judgements. 
Will You to the utmost of Your power Maintaine the Laws of God the true Profession of the Gospell and the Protestant Reformed Religion Established by Law? And will You Preserve unto the Bishops and Clergy of this Realme and to the Churches committed to their Charge all such Rights and Priviledges as by Law doe or shall appertaine unto them or any of them.

Following the answers, the monarch kisses the Bible having declared 'The things which I have here before promised I will performe and Keepe Soe help me God.'

\section{DEVELOPMENT IN THE FORM OF THE OATH SINCE 1688}

Lambeth Palace Library holds the service books used in coronations, with various manuscript amendments. ${ }^{1}$ From those it is possible to chart the amendments in the form of the oath administered from the coronation of Queen Anne to the present. There have been considerable textual amendments, all achieved without express amendment of the 1688 Act itself. It is not proposed to dwell on the amendments made throughout the eighteenth and nineteenth centuries but we might look at the detail of two amendments for the coronation of George I as exemplars of the way in which the oath has been changed.

In George I's oath, 'this Kingdom of England' is amended to 'this Kingdom of Great Britain' in the first part of the oath. ${ }^{2}$ In the third part of the oath the amendments are more considerable. After the oath to maintain 'the Protestant Reformed Religion Established by Law', the following is inserted:

And will you maintain and preserve inviolably the settlement of the Church of England and the Doctrine, Worship, Discipline \& Government thereof as by law established within the Kingdoms of England and Ireland, the Dominion of Wales \& Town of Berwick upon Tweed and the Territories thereunto belonging before the Union of the two Kingdoms.

There is an express statutory authority for the insertion of this latter text. Section II of the Act of 6 Anne 1706, requires all sovereigns subsequent to Queen Anne to take, at their coronations, an oath preserving the settlement of the English Church. ${ }^{3}$ The manuscript for the service of George II records that this insertion

1 Many thanks are due from the author to Steph Eeles of Lambeth Palace Library for the invaluable assistance provided in supplying the extracts mentioned.

2 Lambeth MS 1078; this is, in fact, Queen Anne's service book with manuscript amendments.

36 Anne 1706: An Act for securing the Church of England as by Law established. Section III required that this Act be 'a fundamental and essential Part of any Treaty of Union'. In the Union with Scotland Act 1706, the requirement to take the new oath is expressly included at Art XXV, section III. In the 
was settled by the attorney-general, Sir Edward Northey, in George I's time. ${ }^{4}$ The insertion brought the oath into conformity with statute.

The replacement of England with Great Britain in the oath is the natural consequence of Article I of both Acts of Union that the two kingdoms of England and Scotland be ever after united. England, as a sovereign state, ceased to exist. ${ }^{5}$ This looks very much like an instance of implied amendment, as described in Bennion on Statutory Interpretation:

Where a later enactment does not expressly amend (whether textually or indirectly) an earlier enactment which it has power to override, but the provisions of the later enactment are inconsistent with those of the earlier, the later by implication amends the earlier so far as is necessary to remove the inconsistency between them. ${ }^{6}$

An alternative view relies on another canon of statutory construction, namely that:

In construing an ongoing Act, the interpreter is to presume that Parliament intended the Act to be applied at any future time in such a way as to give effect to the true original intention. Accordingly the interpreter is to make allowances for any relevant changes that have occurred, since the Act's passing, in law ...?

As a further brief example, in George IV's oath, the third part of the oath was amended to a promise to maintain the settlement of the united English and Irish churches. ${ }^{8}$ This was occasioned by provisions in the Treaty of Union between Great Britain and Ireland, the fifth article of which provided 'that the

Union with England Act 1707, Art XXV merely declares 'that the Parliament of England may provide for the security of the Church of England as they think expedient to take place within the bounds of the said Kingdom of England'.

4 Lambeth MS 1079a.

5 In English jurisprudence, the union has been regarded as having abolished the parliaments of England and Scotland and having created a Parliament of Great Britain with supreme authority to legislate for the new, united, kingdom. See, for example, A Dicey and R Rait, Thoughts on the Union between England and Scotland (London, 1920), esp pp v-vi. In Scotland meanwhile, even while doubting whether the Parliament of Great Britain was fully sovereign, the Lord President's famous judgment in MacCormick v Lord Advocate 1953 SC 396 acknowledges that the Treaty of Union 'extinguished' the parliaments of England and Scotland.

$6 \mathrm{O}$ Jones and F Bennion, Bennion on Statutory Interpretation (sixth edition, London, 2013), s 80.

7 Ibid, s 288. See, however, Oxfordshire CC v Oxford City Council [2006] Ch 43, where the Court of Appeal doubted whether changes themselves brought about by statute should be subject to this rule. Carnnwath LJ suggested (at para 85) that, where a change in the extraneous circumstances alleged to affect the construction of an older statute is brought about by a newer statute, the precise extent of that change should not be looked for beyond the newer statute.

8 Lambeth KA 113 (1821); this is the order of service actually signed by George IV (the signature is rather smudged). 
churches of England and Ireland, as now by law established, be united into one protestant episcopal church, to be called, "The united church of England and Ireland"'.

In the twentieth century, references to the Irish Church were removed from the oath, the Church of Ireland having been disestablished. The question about the authority for these changes in the oath had been raised prior to Edward VII's coronation and this gives some insight into how the legality of the amendments were regarded at the start of that century. The Lord Chancellor, Lord Halsbury, held the (correct) view that specific legislation was not called for because the removal of references in the oath to the Irish Church was sanctioned by section 69 of the Irish Church Act 1869:

In all enactments, deeds, and other documents in which mention is made of the United Church of England and Ireland, the enactments and provisions relating thereto shall be read distributively in respect of the Church of England and the Church of Ireland, but, as to the lastmentioned Church, subject to the provisions of this Act. ${ }^{9}$

However, in the House of Commons, Arthur Balfour stated that, to effect a change, an Act making express amendments would be necessary. ${ }^{10}$ In the House of Lords, the basis for the amendment of the oath was put forward by Lord Stanmore (not a lawyer) as being the exercise of the 'Sovereign's prerogative." ${ }^{11}$

At the time of the passage of the Irish Church Act, Lord Granville advised the House of Lords that the references to the Church of Ireland had been added to George IV's oath (the first taken after the union with Ireland) by Order in Council, the law officers having given their opinion that the Privy Council was competent to alter the words. ${ }^{12}$ This looks therefore like another example of executive drafting in response to statutory change.

Down to the time of George VI, while the form of the oath changed without any express amendment of the 1688 Act, statutory authority could be produced for each variation. George VI's oath, though, is problematic. The first and third parts read as follows:

10 HC Deb 15 February 1901, vol 89, cols 178-179. HC Deb 13 August 1901, vol 99, col 624, reports a bill to amend the 'coronation oath' but in fact that bill was designed merely to alter the form of the declaration against various Roman Catholic beliefs. A copy of this bill and a report of the select committee of the House of Lords were helpfully supplied by Heather Evennett, senior library clerk at the House of Lords, to whom the author's grateful thanks are due. The bill proposed that the declaration be pared down and, although the bill was not enacted, the declaration was eventually pared down even further by the Accession Declaration Act 1910.

11 HL Deb 12 May 1902, vol 107, col 1318.

12 HL Deb 19 April 1869, vol 195, col 1068. 
Will you solemnly promise and swear to govern the peoples of Great Britain, Ireland, Canada, Australia, New Zealand and the Union of South Africa, of your Possessions and the other Territories to any of them belonging or pertaining, and of your Empire of India, according to their respective laws and customs?

Will you to the utmost of your power maintain the Laws of God and the true profession of the Gospel? Will you to the utmost of your power maintain in the United Kingdom the Protestant Reformed Religion established by law? And will you maintain and preserve inviolably the settlement of the Church of England, and the doctrine, worship, discipline, and government thereof, as by law established in England? And will you preserve unto the Bishops and Clergy of England, and to the Churches there committed to their charge, all such rights and privileges, as by law do or shall appertain to them, or any of them? ${ }^{13}$

The opinion of the Government was that 'The Statute of Westminster and the Declaration of the Imperial Conference of 1926 referred to in the Preamble of that Statute necessitated the changes which have been made in the oath administered at the Coronation of King George V. ${ }^{, 14}$ The view was that amending legislation was not required for changes necessary in order to bring the words of the oath into harmony with statutes passed from time to time. The only authority cited was previous practice. ${ }^{15}$ The German antiquary Percy Ernest Schramm notes that the Privy Council altered the oath and published the new form in the public press on 20 February $1937 .{ }^{16}$ An article in the Sydney Morning Herald of that date reported that the change in the oath was announced in Australia by the Prime Minister, Joseph Lyons. Lyons advised that the new oath was drafted following agreement by the members of the 'British Commonwealth of Nations' and was required because the old oath 'did not indicate the existing constitutional position of the British Commonwealth, following on the 1926 declaration of equality of status, and the subsequent passing of the Statute of Westminster'. ${ }^{17}$

In the first part of the oath, the promise to govern the people of the United Kingdom of Great Britain and Ireland and the dominions thereto belonging is

13 Lambeth KA 113 (1937); signed by the King and his consort (each more assured than George IV's signature).

14 HC Deb 17 March 1937, vol 321, col 2098W, Ramsay McDonald answering as Lord President of the Council.

15 Ibid.

16 P Schramm, A History of the English Coronation (Oxford, 1937), p 273. The present article relies heavily on this work for the history of the oath prior to the passage of the 1688 Act.

17 Sydney Morning Herald, 20 February 1937, p 17, available at <http://trove.nla.gov.au/newspaper/ article $/ 17305392$ ? browse=ndp\%3Abrowse\%2 Fdate\%2 F1937\%2Fo2\%2F20\%2Ftitle\%2 ${ }_{2}$ F $_{3} \%$

2Fpage\%2F1137201\%2Farticle\%2F17305392>, accessed 7 June 2017. 
replaced with a reference to Great Britain, Ireland and certain of the dominions listed in the Statute of Westminster $1931 .^{18}$ With the exception of Ireland, ${ }^{19}$ there seems little controversy that the dominions recited in George VI's oath were dominions belonging to the United Kingdom ${ }^{20}$ and their express mention is probably justified on the basis of the 'true original intention' doctrine referred to above. ${ }^{21}$

However, the first part of the oath also omitted the reference to govern 'according to the statutes in Parliament agreed upon' and this change is both profound and not easy to justify. The reference to Parliament could have been construed as a recognition of Parliament's continuing right to legislate for the dominions when, in fact, this had been constrained by the 1931 Statute. ${ }^{22}$ The omission may thus have been thought necessary to make clear this diminution in Parliament's power. If that was the motivation, then it may have been thought that Parliament's supremacy within the United Kingdom was amply protected by reference to the 'laws and customs of the same', Parliament's sovereignty having been so clearly established since 1688 as to no longer require specific mention.

However, one of the major concerns of the legislation consolidating the Glorious Revolution (see the Bill of Rights 1688) was the assertion of the supremacy and sovereignty of Parliament (the other being the institution of the Protestant succession, although the two were closely linked). ${ }^{23}$ The absence of any reference to Parliament as the ultimate source of the laws of the realm does, in theory, reignite old controversies which date to the days of

18 Newfoundland was listed as a dominion in the Statute of Westminster but, by the time of George VI's coronation, responsibility for its government had reverted to commissioners under the United Kingdom Government, pursuant to the Newfoundland Act 1933.

19 The Irish Free State was listed as a dominion in the Statute of Westminster but the oath continues to mention Ireland, though partitioned, in its entirety as the British sovereign was arguably head of state of both jurisdictions in Ireland. In fact, the position of the Crown in that part that is now the Republic of Ireland was uncertain by 1937. A full discussion is outside the scope of this article but see John Coakley, 'An ambiguous office? The position of head of state in the Irish Constitution', (2012) 48 Irish Jurist 43-70.

20 At least for the purposes of the 1688 Act. Whether, otherwise, the dominions 'belonged' to the United Kingdom is debatable on account of the legislative independence accorded to them by the Statute of Westminster. 'Belong' is probably not a word that that can be used in any legal context without considerable qualification.

21 While the Statute of Westminster expressly defines 'dominion', the definition is expressly limited to that statute. The failure to give the term wider statutory significance might be thought, on the basis of Oxfordshire CCv Oxford City Council [2006] Ch 43 (CA), to contain the definition strictly within the 1931 Statute.

22 Statute of Westminster 1931, S 4. The preamble recited 'that any alteration in the law touching the Succession to the Throne or the Royal Style and Titles shall hereafter require the assent as well of the Parliaments of all the Dominions as of the Parliament of the United Kingdom'. A Twomey, 'Changing the rules of succession to the throne' (2011) 2:2 Public Law 378-401, is dismissive of the idea that this constitutes a legal barrier to unilateral legislation by the British Parliament on this subject for purely British purposes.

23 If authority were required for this axiomatic proposition, reliance would be on the second recital of the Bill of Rights 1688. This complained of the monarch's assumed power 'of Dispensing with and Suspending of Lawes and the Execution of Lawes without Consent of Parlyament'. 
Charles I and, in fact, further back to Edward II's time (on which more below). That might be thought unlikely. However, while until very recently indeed Parliament's sovereignty would simply have been assumed, issues surrounding the United Kingdom's relationship with what is now the European Union have cast doubt on this. For a time, the threat was believed to come from EU law itself. ${ }^{24}$ However, section 18 of the European Union Act 2011 declared that EU law depended on Acts of Parliament; in the aftermath of the EU referendum, it has not seriously been argued that Parliament has no right to repeal the European Communities Act 1972. ${ }^{25}$ Perhaps, though, referendums themselves pose new, subtle threats to parliamentary sovereignty. At the time of writing the general consensus is that the United Kingdom Parliament would not have voted to leave the EU had it been charged with making that decision alone. ${ }^{26}$ As a matter of political reality, however, Parliament appears to have transferred the decision to the whole electorate.

Leaving the issue of Europe aside, the fact remains that the assertion of parliamentary sovereignty in the Bill of Rights has immense constitutional significance. The monarch's explicit recognition, under the 1688 Act, of Parliament's sovereignty is inextricably part of the constitutional settlement which founded the modern British state. The Divisional Court in Thoburn v Sunderland City Council was correct in categorising the Bill of Rights as a constitutional statute with special status which could not be impliedly repealed. ${ }^{27}$ The same is surely true of those provisions of the 1688 Act which recite the parliamentary supremacy. Even if these statutes can be impliedly repealed it is difficult to see how the Statute of Westminster has given statutory authority for the removal of the reference to Parliament in the 1688 Act. $^{28}$ The Statute weakened Parliament's power in the dominions; it said absolutely nothing about its authority within the United Kingdom. Accordingly, the removal of references to Parliament in the 1937 version of the oath are not warranted by the Statute of Westminster and must rest on some other express statutory authority.

24 For example, Lord Bridge of Harwich's speech in $R v$ Secretary of State for Transport, Ex $p$ Factortame Ltd (No 2) [1991] 1 AC 603 (HL) at 658-659: 'affirming the jurisdiction of the courts of member states to override national legislation if necessary to enable interim relief to be granted in protection of rights under Community law'.

Which right was, of course, never doubted by the courts.

The matter was serious enough for one opposition MP to feel the need to assert Parliament's sovereignty. HC Deb 11 July 2016, vol 613, col 27: 'Is it not the case that referendums are advisory and that this Parliament is sovereign? Is it not a constitutional outrage and supreme irony that those on the Conservative Benches who based their argument for Brexit on parliamentary sovereignty now want to deny this House a vote and are suggesting that an unelected Prime Minister, with no mandate, agrees to such a fundamental decision for this country?' As is well known, however, Parliament had the final say: $R$ (Miller) $v$ Secretary of State for Exiting the European Union [2017] 1 All ER 593. [2003] QB 151 at paras 62-63. See also H v Lord Advocate [2013] 1 AC 413 (HL).

28 See F Ahmed and A Perry, 'The quasi-entrenchment of constitutional statutes', (2014) 73:3 CLJ 514-535, for a view that the statutes can be impliedly repealed. 
As noted above, Schramm states that the Privy Council altered the oath in accordance with previous practice. ${ }^{29}$ However, the Council only has two sources of power to legislate: the royal prerogative and statutory authority. ${ }^{30}$ As for the first source, no statute can be amended by the prerogative. ${ }^{31}$ As to the second, in 1953 the Prime Minister told the House of Commons that the oath had never been amended by statute (see further below). As we have seen this must refer to express amendments: the material changes since 1688 have had the authority of one statute or another. However, as just observed, the authority stated by the Government in 1937 for the changes to George VI's oath, the 1931 Statute, does not in fact permit the removal of references to Parliament. In 1953 the Government was not able to point to any other statutory authority for the changes. It therefore seems very likely that the omission of references to Parliament does not have the sanction of statute. Accordingly, we must, with reluctance, conclude that any oath administered at a coronation is unlawful if it does not, in its first part, refer to Parliament.

In passing, we might note another part of the 1937 oath that is devoid of statutory authority: the reference to the maintenance of the Protestant religion in the United Kingdom. The position in England is clear: the Church of England is established. The requirement to uphold the Protestant faith in Scotland is unremarkable on account of the fact that, by the provisions of the Treaty of Union, the monarch must swear to maintain the 'true Protestant Religion' in Scotland. ${ }^{32}$ However, the Irish Church was disestablished by the Irish Church Act 1869 and there has likewise been no established church in Wales since the coming into force of the Welsh Church Act 1914 in $1920 .{ }^{33}$ A regent swears merely to, 'maintain and preserve in England and in Scotland the Settlement of the true Protestant religion', and this oath more accurately represents the correct constitutional position. ${ }^{34}$

The version of the oath in 1953 contained a different list of countries from that of 1937 in the first part. This obviously reflected the continuing retreat from empire. Only Northern Ireland is now mentioned. The reference to the statutes in Parliament agreed upon remained absent. The promise to maintain the

29 Schramm, History of the English Coronation, p 273, note to p 226. Schramm was not a lawyer but he too queries how the Statute of Westminster could be relied on as the authority for the removal of references to Parliament.

30 P Jackson and P Leopold, O. Hood Phillips and Jackson: constitutional and administrative law (eighth edition, London, 2001), para 16-005.

31 The combined effect of the Case of Proclamations (1610) 12 Co Rep 74; 77 ER 1352; and those provisions of the Bill of Rights which prohibit suspending and dispensing with statute. See Miller, esp at para 45 .

32 Union with Scotland Act 1706, Art XXV; Union with England Act 1707, Art XXV. The Church of Scotland's position as an 'established church' is sometimes doubted: See M MacLean, Legal Systems of Scottish Churches (Dundee, 2009), p 2.

33 Welsh Church (Temporalities) Act 1919, s 2.

34 Regency Act 1937, sch, para 3. 
Protestant Reformed religion continued to extend to the whole of the United Kingdom. ${ }^{35}$

At the last coronation, the Prime Minister, Winston Churchill, relying on the advice of the Lord Chancellor, in answer to a written question, gave his opinion to the House of Commons that none of the changes since 1688 had 'legislative sanction'. ${ }^{36}$ He said that, at the time of the coronation of George VI, the Lord Chancellor and law officers had stated that no Act of Parliament was required for changes to the oath. In response to this another member asked whether:

in view of the fact that the Coronation Oath is a Parliamentary creation, and is intended as a limitation on the Prerogative, is it not desirable, though it may be inconvenient, that any changes that are proposed this year should have legislative sanction ... ${ }^{37}$

This was met with a referral back to the Prime Minister's main statement, which had included the government's view that:

To accept the view that changes in the terms of the Oath which are necessary to reconcile it with a changed constitutional position cannot be made except with the authority of an Act of Parliament would be to cast doubt upon the validity of the Oath administered to every Sovereign of this country since George I. ${ }^{38}$

The politician's response was that it would be dangerous, indeed impossible, to conclude that invalid oaths had been taken in the past. The law, however, will not permit recourse to such expediency. Before enquiring into how the law might respond, some historical context will be provided on the importance of the sovereign's subservience to the Crown in Parliament which the statutory form of the oath clearly annunciates.

\section{A HISTORICAL DETOUR}

Mention was made above about controversies dating back to the reign of Edward II. These reveal that, since mediaeval times, the terms of the coronation oath

L Maer and O Gay, 'The coronation oath', appendix B, available at <www.Parliament.uk/briefingpapers/SNoo435.pdf>, accessed 7 June 2017. The oath taken by the present Queen is also to be found in film footage online and this perhaps represents the best way of discovering which form of the oath was actually spoken by the sovereign. The possibility of divergence from the written service cannot be discounted. When the oath administered to President Obama was found to be other than in the form prescribed by Article II of the US Constitution, he retook it: 'Barack Obama retakes oath after mistakes at inauguration', Daily Telegraph, 22 January 2009.

36 HC Deb 25 February 1953, vol 511, col 2091.

37 Ibid, col 2092.

38 Ibid, cols 2091-2092. 
have reflected the conflict for ascendancy between sovereign and subjects. ${ }^{39}$ The English coronation oath dates to the Anglo-Saxon period, but only at the coronation of Edward II in 1308 was it cast for the first time as a series of questions and answers:

Will you grant and keep and by your oath confirm to the people of England the laws and customs granted to them by the ancient kings of England your righteous and godly predecessors, and especially the laws, customs and privileges granted to the clergy and people by the glorious King Saint Edward your predecessor?

Will you keep towards God and holy church and to clergy and people peace and accord in God entirely after your power?

Will you cause to be done in all your judgments equal and right justice and discretion in mercy and truth to your power?

Do you grant to hold and keep the laws and righteous customs which the community of your realm shall have chosen [quas vulgus elegerit], and will you defend and strengthen them to the honour of God to the utmost of your power? $4^{\circ}$

The changes to the oath were a response to the constitutional developments of the thirteen century. That century had witnessed a struggle between the king and the barons, in the course of which Magna Carta was granted, de Montfort's revolt occurred and Parliament (on which Henry III came to rely for increased grants of revenue) emerged. The new oath was extracted at the beginning of the reign of Edward II, whom the barons anticipated would be more pliable than his father, Edward I. ${ }^{41}$ The great change brought about by this new oath lay in the promise to keep the laws and righteous customs which the community of the realm 'shall have chosen' (quas vulgus elegerit) in the forthcoming Parliament. ${ }^{42}$ The significance of this lies in the king's consent to be bound by new laws as well as the established laws and customs of the realm and, further, his acknowledgment that he must share the law-making power with the assembly of the people. While the new form of the oath obviously did not

39 The interested reader is referred to Schramm, History of the English Coronation, and L G Wickham Legg, English Coronation Records (Westminster, 1901), for the history of the oath prior to the passage of the 1688 Act.

40 F W Maitland, Constitutional History of England (Cambridge, 1911), p 99; this was Maitland's translation from the Latin.

41 Schramm, History of the English Coronation, pp 204-206, suggests that the inelegant drafting is suggestive of concessions wrung out of Edward II at the very last moment before he was crowned.

42 Ibid, p 207. The meaning of elegerit - specifically whether it refers to the future or past - has been controversial. Maitland and Schramm both say that it applies to future laws. Uncertainty is added by the existence of contemporary French versions of the oath. In Latin, elegerit is the third person singular form of both the future perfect indicative active and the perfect subjunctive active of the verb elegere. It could therefore mean either 'shall have chosen (in the future)' or 'may have chosen (in the past)'. The latter form does not seem appropriate when referring to the settled laws of the realm. 
establish parliamentary government, it does perhaps mark a new period in which the king was obliged to recognise not just the concerns of the magnates but those of the wider populace. ${ }^{43}$

Richard II diluted the promise to keep the laws which the people shall choose by the insertion of 'justly and reasonably'. ${ }^{44}$ Henry VIII, meanwhile, is believed to have personally amended the fourth question in manuscript, so that his promise (with the king's additions emphasised) was to

graunte to hold the laws and approvyd customes of the realm lawfull and nott prejudicial to his Crowne or Imperiall duty and to his power kepe them and affirm them which the nobles and people have made and chosen with his consent. ${ }^{45}$

At the coronation of Charles I, the king swore merely to 'keep the laws and rightful customs which the communality of this your kingdom have', which on a literal interpretation appeared to leave no scope for further popular legislative change. ${ }^{46}$ When Charles was tried before the High Court of Justice at the conclusion of the Wars of the Three Kingdoms, the omission from the oath of the words 'that the people shall choose' was explicitly cited as an instance of the King's absolutist tendencies: 'that so when the Parliament should tender good laws to him for the royal assent, he might readily answer that he was not by Oath obliged to confirm or corroborate the same'. ${ }^{47}$

It was Parliament's desire to constrain the monarchy after the disastrous reigns of Charles I and James II that prompted the enactment of the 1688 Act. When resolving that James II had left the throne vacant, the House of Commons referred to the coronation oath by reciting that the King had subverted the constitution of the kingdom, 'by breaking the original contract between King and people'. ${ }^{8}$

Maitland, is explicit that 'the statutes in Parliament agreed on' take the place of leges quas vulgus elegerit. ${ }^{49}$ The omission of that part of the oath challenges not only the Williamite settlement (on which the constitution largely rests even to this day) but, arguably, older ideas of the limits on regal (now, of course, executive) power.

43 For example in 1295, for the first time, two burgesses from each borough were summoned to Parliament: Maitland, Constitutional History, p 74.

44 Schramm, History of the English Coronation, p 212.

45 Maitland, Constitutional History, p 287; Wickham Legg, English Coronation Records, p 241. Wickham Legg doubts that the administered oath contains the king's personal amendments (ibid, p 240, where the manuscript document appears in facsimile). Drawing on comments of G R Elton, The Tudor Constitution (Cambridge, 1965), p 20, $\mathrm{n}$ 2, it is tempting to speculate that the king, at the commencement of his reign, was therefore involved in nothing more than an academic exercise: the flight of fancy of an accomplished young man on taking up a powerful, but limited, position.

46 Schramm, History of the English Coronation, p 218; Wickham Legg, English Coronation Records, p 252.

474 St Tr 990 at 1020 and 1022.

48 House of Commons Journal, vol 10, 28 January 1689.

49 Maitland, Constitutional History, p 288. 
THE CONSEQUENCES OF ADMINISTERING THE INCORRECT FORM OF OATH

Faced with the (literally) unsettling proposition that unlawful oaths had been administered in the past, Churchill's administration fell back on political expediency. The law has not that comfort. At the same time, however, lawyers will be hesitant to conclude that unlawful oaths equal unlawful reigns and the constitutional chaos that would ensue..$^{50}$ The aim therefore is to find legal means to support the lawfulness of a reign that has commenced with an irregular oath.

The starting point here is to note that taking the oath is neither a prerequisite to the accession to the Crown nor to provision of the royal assent. Edward VIII never took the oath but gave royal assent to Acts throughout his 325-day reign, including the Act which ended it..$^{11}$ However, section 4 of the 1688 Act requires the oath to be administered to every king or queen at their respective coronations and section 2 of the Act of Settlement repeats this requirement. The view of the editors of Halsbury's Laws is that administration of the oath, 'in the form provided by statute', is a condition on which the Crown is held. ${ }^{52}$ Those who drafted the 1688 Act clearly wished the monarch to solemnise a compact with his people at the sacred act of coronation; but they knew that delay between accession and coronation was commonplace. ${ }^{53}$ From this we can conclude that the oath did not have to be taken immediately and that the Crown could be enjoyed before the oath was taken. Nevertheless, it is not safe to deduce from this that, when the coronation did come, the monarch would be excused taking any oath other than that prescribed by law. Accordingly, the 1688 Act may properly be relied on by the courts in recognising the person entitled to exercise the functions of the sovereign. Any failure to take the oath, or to take it in the correct form, constitutes a legal disability.

\section{THE LAW'S RESPONSE: TWO SUGGESTIONS}

In Ball $v$ The Crown the claimant brought a rather unusual action seeking to contest the validity of Elizabeth II's position as sovereign. ${ }^{54}$ The Court of Appeal noted:

Every person who inherits the Crown is subject to certain conditions, which include taking the coronation oath in the form provided by

50 Litigants in person, on the other hand, often seek comfort in precisely such chaos: $R$ (Cohen) $v$ HMRC [2015] EWHC 1099 (Admin) at para 6.

51 His Majesty's Declaration of Abdication Act 1936. Blackstone, I Comm 236 says that allegiance is owed to the sovereign whether he or she ever takes the oath at all.

52 Halsbury's Laws (fifth edition, London, 2014), vol 20, para 48.

53 Charles II returned to England from exile on 29 May 1660 and his English coronation was held on 23 April 1661. The hiatus between proclamation and coronation was two years in the case of Edward I: Schramm, History of the English Coronation, p 166. 
statute. Every monarch sitting on the throne at the House of Lords must take the laid down declaration. That process has been carried out for monarchs for a long time and, in particular, by our Queen. She has been accepted by Parliament, and by the nation, as the rightful person to inherit the Crown as of the date of her coronation. In those circumstances, it is not now, in the year 2000, open to Mr Ball to challenge her right to the succession which took place.

Mr Ball may be right that there are no statuary limitation periods which would prevent him from raising an attack upon the present Queen's right to the throne; but the length of time and the events that have passed means that this court would not entertain an attack as such would amount to an abuse of the process of the court. This is particularly so, in my view, when the alleged defect in title stems from an alleged bigamous marriage of George III. ${ }^{55}$

This opens up the possibility that a sovereign who had taken a form of the oath that was strictly unlawful would nevertheless be lawfully sovereign pursuant to lengthy occupancy of the throne. This looks like prescription: the acceptance that any right enjoyed for a long time has a lawful origin. ${ }^{56}$ That was not, however, the ground on which Mr Ball's action foundered. Rather, the court's refusal to entertain Mr Ball's claim was stated to rest on abuse of process. Abuse of process, though, like limitation, is essentially a procedural rule of the courts: it bars claims but it does not (at least, not directly) create rights. Suppose that unauthorised oaths had been administered to successive sovereigns; we might prefer to conclude that our present sovereign had a positive right to the Crown as opposed merely to procedural protection from dilatory suits. It is submitted that in Ball it is possible to discern the notion that the sovereign's right to the Crown is dependent not on a procedural rule but rather on the fact that:

It is a maxim of the law of England to give effect to everything which appears to have been established for a considerable course of time, and to presume that what has been done was done of right, and not in wrong. ${ }^{57}$

To the extent that such a maxim does not already apply to the Crown, it is submitted that now is the time to recognise it. However, the example of Henry VII, who seized the Crown from Richard III, should suffice to show that something akin to prescription is already recognised in the law of succession. 
Blackstone and Maitland were both of the view that Henry had no hereditary right. ${ }^{58}$ The recognition of his title, following his victory at Bosworth, therefore raised problems. According to Blackstone, Henry did not wish his title to derive solely from Parliament, for that would have suggested that he had no prior right. Parliament, while prepared to recognise the king's reign, was concerned to avoid precisely the suggestion that he had any such prior right. A middle way was thus devised whereby the inheritance of the Crown was said to 'rest, remain and abide in King Henry VII and the heirs of his body'. This acknowledged the reality of his reign without determining either way whether that reign was de jure or de facto. As events transpired, Henry VII's was the last successful usurpation before the Glorious Revolution and his reign effectively settled the succession for 200 years. It would be difficult now to argue that any of the Tudors or Stuarts who succeeded though him were anything other than de jure monarchs.

There are, however, limits to reliance on prescription. First, the ability to acquire anything other than an incorporeal hereditament by prescription is doubted. ${ }^{59}$ Second, at common law, prescription is dependent on the maintenance of the fictitious belief that the right claimed has a lawful origin. The exposure of the fiction is fatal to the property claimed by prescription. ${ }^{60}$ In the case of the coronation oath, the fiction that the 1688 Act has been lawfully adhered to is difficult to maintain in the face of such well-documented evidence to the contrary. Third, prescription is largely the law's pragmatic response to the problem of how to recognise long-established de facto possession. ${ }^{61}$ It might be objected that such pragmatism is incompatible with a central doctrine of the Williamite settlement, namely that the succession should be orderly and governed by statute.

Reliance on prescription may be thought to be unpersuasive. Yet there is a desire discernible from the Ball case and from our history to accord legality to long possession of the Crown. We might say that tension exists between a long, peaceful and successful reign on the one hand and failure to conform strictly to the 1688 Act on the other. While prescription may not resolve the tension, it may be that another feature of property law can.

Before exploring this means of resolution, it might be best to say something about the Crown as property by way of apology for reliance on property law

58 Blackstone, I Comm 204; Maitland, Constitutional History, p 195.

59 Blackstone, II Comm 264. A peerage is an incorporeal hereditament: Viscountess Rhondda's Claim [1922] 2 AC 339 (HL) esp at 393. The Crown, however, for reasons relating to seisin discussed in the text, would appear not to be. However, Erskine May: parliamentary practice (24th edition, London, 2011), p 2, asserts that 'the King or Queen has always enjoyed by prescription, custom and law, the chief place in Parliament and the sole executive power'.

6o In the case of easements, at common law the prescriptive period is 'from time immemorial', ie 1189 . In practice, significantly shorter periods could be relied on; however, if it could be positively shown that use of, for example, a right of way would have been impossible at some point since 1189, the fiction would collapse in the face of this truth: Hulbert v Dale [1909] 2 Ch 570 at 577.

61 See eg $R v$ Oxfordshire CC ex parte Sunningwell [2000] 1 AC 335 (HL) at 349 (Lord Hoffman). 
solutions for a public law problem. In Possession in the Common Law, Pollock and Wright remarked that 'The King is not unfrequently spoken of as being seised or possessed of the Crown'. ${ }^{62}$ Writing, this time with F W Maitland, in the History of English Law, Pollock said of the Crown in the thirteenth century:

The kingly power is a mode of dominium; the ownership of a chattel, the lordship, the tenancy, of lands, these are also modes of dominium. We may argue backwards and forwards between the kingly right and the rights of private landholders. This is the more remarkable in the case of inheritance, for, as is well known, the notion that kingship is in some sort elective is but slowly dying. For all this, the king is conceived to hold his lands by a strict hereditary right, and between his lands and the kingship it would be hard to distinguish. ${ }^{63}$

There is therefore a long tradition of viewing the Crown and property as either synonymous or, at least, concepts which cannot easily be disentangled. ${ }^{64}$ In passing, note that if the king is seised of the Crown then the property which the king thereby holds is akin to corporeal, as opposed to incorporeal, property: one cannot be seised of anything less than freehold. ${ }^{65}$

Formerly in English law (and still in the law of Northern Ireland) there was a requirement that a contract for the sale of land had to be evidenced in writing. ${ }^{66}$ There was often no writing, but one party had performed certain provisions of the contract. In such a case it was thought to be unjust for the other party to be able to deny the contract on the grounds that the formality provisions in the statute had not been met. Equity developed the doctrine of part performance, under which:

the Court will not allow a statute which was passed to prevent fraud to be made itself an instrument of fraud. In other words, the court disregards the absence of that formality which the statute requires when insistence upon it would render it a means of effecting, instead of a means of averting, fraud. ${ }^{67}$

As explained by the House of Lords, the point of the doctrine is to allow an examination of the circumstances to determine whether the acts of part performance

62 F Pollock and R Wright, Possession in the Common Law (Oxford, 1888), p 36.

63 F Pollock and F W Maitland, The History of English Law (second edition, Cambridge, 1898), vol I, p 497; see also pp 504-510.

64 Schramm, History of the English Coronation, p 2, notes a similar elision in Teutonic custom. He says: 'the government of a country was taken over in the same way as a private estate'.

65 Pollock and Wright, Possession in the Common Law, p 47.

66 Statute of Frauds (1677), s 4. In England and Wales, the contract itself must now be in writing.

67 Lowry v Reid [1927] NI 142. 
indicate the existence of the agreement. ${ }^{68}$ If they do, then the absence of statutory formality is not a bar to the recognition of the agreement.

The analogy between failure to conform to the 1688 Act and failure to conform to the Statute of Frauds is far from direct. There are any number of dissimilarities, of which only the most obvious is stated here: namely, that the doctrine of part performance is used by one party to a civil action in circumstances where it would be inequitable to allow the other party to deny a simple contract.

However, there are two aspects of the equitable doctrine of part performance which could be built upon to construct a doctrine which would ameliorate failures to adhere to the correct statutory form of coronation oath. The first is the equitable jurisdiction, entirely the innovation of the Court of Chancery ${ }^{6}$ (after all, not past the age of childbearing ${ }^{70}$ ), to disapply a very clearly imposed statutory formality. The second is the equitable search for the substance rather than the form. The statute says: no writing, no enforceability. Equity asks, rather: do the circumstances establish that there is a contract which should be recognised? If so, the party seeking to rely on it is placed in the same position that he or she would have been in had the statutory formalities been adhered to.

In the case of the sovereign, the quest might be, likewise, to establish whether the circumstances show that, even if the statutory formality has not been adhered to, the sovereign's conduct recognises the compact between her and her people that the oath envisages. If the sovereign has observed that conduct which the oath requires, we might be permitted to conclude that the person taking the oath should be regarded by the law as being in the same position as if the oath had been correctly taken.

This does not mean that the quest is to find out whether the sovereign has kept the oath. This is just as well because the courts would be most reluctant to make the sovereign's behaviour subject to their process on the basis of a religious oath framed largely in the sectarian strife of the late seventeenth century. $R$ $v$ Lord Chancellor ex $p$ Green shows this reticence very clearly. ${ }^{71}$ In that case, an application was brought to prevent the Lord Chancellor from placing the Family Law Bill before Her Majesty for the royal assent. The grounds were that the bill undermined the permanence of marriage and was thus contrary to that part of the oath to "maintain the laws of God and the true profession of the Gospel'. Sedley J, refusing the application in very short order, held that the Queen was constitutionally bound to give her assent to those statutory measures which had been approved by the Lords and Commons: 
The court is here to give effect to legislation if and when it is the will of Parliament that it should become part of our statute law. Her Majesty, too, is constitutionally called upon to give her assent to those statutory measures which it is the will of the Lords and Commons should become law. It is to that and no other end that the Lord Chancellor will place the measure before Her Majesty. It will be his duty to do so ... ${ }^{72}$

The aim, rather, is to determine whether the sovereign has acted as if bound by an agreement. We might decide that a reign conducted in accordance with the concerns expressed in the 1688 Act (as validly amended) is sufficient to prevent the legality of the oath on which that reign rests from being called into question. The minimum content of that conduct (based on the form of the oath that has statutory authority) is tentatively suggested here to be respect for parliamentary government and respect for the establishment of the Church of England. Others can judge; but it is submitted here that both have been more than adequately observed by Her Majesty.

\section{CONCLUSION}

The contention here has been that the oath taken by the Queen and her father lacked statutory authority. This cannot simply be ignored. The parliamentary supremacy is not only a major preoccupation of the 1688 Act but is the fundamental rule of our constitution, whose origins are faintly visible in our far-distant history. An oath that does not comply with the 1688 form, as amended, not only violates primary statute law but fails to give due precedence to this central principle. Several devices have been suggested above to mitigate the consequences of the administration of an unlawful oath. If employed, these devices would imperil neither Her Majesty's long and successful reign nor any legislation to which she has graciously assented. 